\title{
FORMALISASI HUKUM ISLAM DALAM BENTUK PERATURAN DAERAH: ANALISIS YURIDIS PETATURAN DAERAH SYARIAH DI BULUKUMBA
}

\author{
Abdul Syatar ${ }^{1}$ \\ Juliana $^{2}$ \\ Zehratul Eitriya ${ }^{3}$ \\ Rifaldi $^{4}$ \\ Winanda ${ }^{5}$ \\ Alfajri Anugrah ${ }^{6}$ \\ Angelina Atika Putri ${ }^{7}$
}

\begin{abstract}
This article aims to examine the formalization of Islamic law in the form of a Sharia Regional Regulation (Perda) in Bulukumba. The approach in this research is juridical-normative. This approach is used to understand the phenomenon of the formalization of Islamic law in the Bulukumba area. The results show that the formalization and application of sharia regulations in Bulukumba is running quite well, this is based on the development of public understanding and compliance with the Perda. On the other hand, these sharia-based regulations sometimes run less effectively. This is because there are still many Bulukumba people who do not know, let alone understand the Sharia Regional Regulations well.
\end{abstract}

Keywords: Perda, formalization of Islamic law, Bulukumba. 


\section{A. Pendahuluan}

Di Indonesia, isu dan wacana penerapan syariat Islam bukan lagi menjadi sesuatu yang baru. Usaha tersebut memiliki akar historis panjang. Anthony Reid ${ }^{1}$ menjelaskan bahwa sejak awal abad ke-17 masehi, hukum Islam yang ketat telah diterapkan secara parsial di Banten (Jawa Barat) dan Aceh, seperti hukum potong tangan yang diberlakukan kepada para pencuri. Hal ini menunjukkan bahwa sejak awal sejarah Islam di Nusantara, wacana syariat Islam telah bergema dan telah menjadi perhatian umat Islam saat itu.

Proses formalisasi syariat Islam di Indonesia cukup menarik dan sejumlah hal mengandung kontroversi. Pro-kontra bergema terkait formalisasi syariat Islam di Indonesia yang sejatinya bukan negara Islam. Gerakan Islam Syariat yang memperjuangkan formalisasi penerapan syariat Islam dalam kehidupan negara di Indonesia muncul secara terbuka pada awal era reformasi. Gerakan ini dimulai oleh usaha sekelompok umat Islam untuk memasukkan kembali Piagam Jakarta dalam Amandemen UUD 1945 pada sidang tahunan MPR-RI tahun 2000. ${ }^{2}$ Formalisasi hukum Islam dalam bentuk perundangundangan di Indonesia mudah ditemukan seperti Undang-Undang Zakat, Undang-Undang Haji dan lain-lainnya. ${ }^{3}$ Saat era reformasi, segala bentuk kebebasan mulai dari kebebasan berpendapat dan berorganisasi diberi ruang seluas-luasnya. Aspirasi setiap kelompok mendapatkan ruang dan diakomodasi oleh negara atau pemerintah. Dalam era otonomi dan desentralisasi, setiap daerah memiliki otoritas dalam batas tertentu untuk mengurus wilayahnya sesuai kehendak masyarakat di daerah tersebut. Peluang tersebut tampaknya memicu kelompok-kelompok masyarakat di beberapa daerah untuk membuat

${ }^{1}$ M. Zainal Anwar, "Formalisasi Syari'at Islam di Indonesia: Pendekatan Pluralisme Politik dalam Kebijakan Publik," Millah: Jurnal Studi Agama 10, no. 2 (2011): 192-221, https://www.academia.edu/25382405/Formalisasi_Syariat_Islam_ di_Indonesia_Pendekatan_Pluralisme_Politik_dalam_Kebijakan_Publik.

${ }^{2}$ Amril Maryolo, "Formalisasi Syariat Islam di Bulukumba (Studi Tentang Peraturan Daerah Keagamaan)" (Yogyakarta: Pascasarjana UIN Sunan Kalijaga, 2017), 1.

${ }^{3}$ Abdul Syatar, "Transformation of Fiqh in The Forms of Hajj and Zakat Legislation," Mazahibuna; Jurnal Perbandingan Mazhab 1, no. 2 Desember (2019): 120-133, http://journal.uin-alauddin.ac.id/index.php/mjpm/article/view/11646. 
kebijakan publik yang bernuansa islami dalam bentuk peraturan daerah yang mengacu pada Syariat Islam. Hal itu menjadi awal gegap gempita wacana syariat Islam di Indonesia pasca orde baru. ${ }^{4}$

Penerapan syariat Islam melalui Peraturan Daerah menjadi populer dan menarik perhatian di setiap daerah kabupaten yang ada di Indonesia. ${ }^{5}$ Lebih khusus di daerah kabupaten yang penduduknya mayoritas Islam. ${ }^{6}$ Krisis moral dan perilaku menyimpang menjadi salah satu alasan dalam upaya penegakan syariat Islam. Di antara sekian banyak kabupaten di Sulawesi Selatan, Bulukumba adalah salah satu kabupaten yang cukup terkenal dalam penerapan Syariat Islam melalui peraturan daerahnya. Dalam tulisan ini akan lebih berfokus pada pengkajian Formalisasi Hukum Islam dalam bentuk Peraturan Daerah (Perda) Syariah yang ada di Bulukumba.

Bulukumba menjadi daerah pertama Sulawesi Selatan yang menerapkan Perda bernuansa syariat. ${ }^{7}$ Sejak tahun 2002 dibawah kepemimpinan H. A. Patabai Pabokori pemerintah telah menerapkan beberapa perda yang bernunsa syariat seperti Perda Nomor 03 Tahun 2002 tentang Larangan Pengawasan Penertiban dan Penjualan Minuman Keras; Perda Nomor 02 Tahun 2003 tentang Pengelolaan Zakat Profesi, Infaq dan Shadaqah; Perda Nomor 05 Tahun 2003 tentang Pakaian Muslim dan Muslimah; dan yang terakhir Perda Nomor 06 Tahun 2003 tentang Pandai Baca Tulis Al-Quran bagi Siswa dan Calon Pengantin.

Pemahaman awal tersebut, menimbulkan gejolak ilmiah tentang tujuan awal kemunculan formalisasi Syariat Islam di

${ }^{4}$ M. Zainal Anwar, "Formalisasi Syari'at Islam di Indonesia: Pendekatan Pluralisme Politik Dalam Kebijakan Publik.”

${ }^{5}$ Dessy Marliani Listianingsih, "Analisis Pelaksanaan Peraturan Daerah Berbasis Syariah Provinsi Aceh dalam Perspektif Hak Asasi Manusia," Staarrecht: Indonesian Constitutional Law Journal 3, no. 1 (2019): 105-128.

${ }^{6}$ Fatimah Halim, “Obsesi Enerapan Syari'at Islam di Wilayah Lokal,” AdDaulah 4, no. 2 (2015): 354-365.

${ }^{7}$ Heriansyah Anugrah and Ridho Al-Hamdi, "Kebijakan Syariah di Akar Rumput: Menelusuri Motif Kebijakan Syariah di Akar Rumput; Menelusuri Motif Politik Terbitnya Peraturan Desa tentang Hukuman Cambuk di Kabupaten Bulukumba," Politea: Jurnal Politik Islam 3, no. 2 (2020): 185-212. 
Bulukumba dalam bentuk Perda. Relevansi formalisasi dan penerapan Perda Syariah di Kabupaten Bulukumba itu sejalan dengan prinsip kedaerahan masyarakat di Bulukumba.

\section{B. Metode Penelitian}

Penelitian ini menggunakan jenis kualitatif deskriptif dengan pendekatan studi kasus dan fenomenalogi yang ada di Bulukumba. Adapun sumber data yang digunakan dalam penelitian ini berupa sumber data sekunder yang merupakan data yang diperoleh secara tidak langsung dari sumbernya tetapi melalui perantara dengan mempelajari berbagai literatur-literatur seperti buku-buku, jurnal, maupun artikel ilmiah yang terkait dengan penelitian ini. Data sekunder berupa data pendukung yang bersumber dari literatur maupun dokumen-dokumen yang terkait dengan Perda syariah yang ada di Bulukumba.

\section{Hasil dan Pembahasan}

\section{Peraturan Daerah (Perda)}

Secara umum, Perda adalah instrumen aturan yang diberikan kepada pemerintah daerah dalam rangka penyelenggaraan pemerintahan daerah masing-masing otonom. Perda adalah peraturan tertinggi yang berada di daerah yang perumusannya melibatkan eksekutif dan legislatif. Perda dibagi menjadi peraturan daerah provinsi dan peraturan daerah kabupaten $/$ kota. $^{8}$

Perda syariah atau perda yang bernuansa syariah adalah istilah untuk peraturan daerah di Indonesia yang berlandaskan hukum agama Islam. Peraturan ini dihasilkan oleh Pemerintah Daerah dan DPRD di tingkat provinsi, kabupaten/kota. Kemunculannya dilatarbelakangi undang-undang otonomi daerah yang mengizinkan pemerintah daerah mengeluarkan peraturan daerah (perda) selama tidak bertentangan dengan undang-undang yang lebih tinggi. ${ }^{9}$

${ }^{8}$ Pemerintah Kabupaten Bulukumba, "Pengertian Produk Hukum Daerah", diakses 29 April 2015. http://www.hukumsetda.bulelengkab.go.id/.

${ }^{9}$ Wikipedia, "Perda Syariah,” diakses pada 24 Februari 2021. https://www.id.m.wikipedia.org/. 


\section{Kebijakan Otonomi Daerah: Awal Munculnya Perda Syariah}

Salah satu tuntutan reformasi di Indonesia adalah penegakan keadilan dalam kehidupan bernegara. Sistem sentralisasi pemerintah dinilai sangat merugikan kepentingan daerah untuk mengelola wilayahnya sendiri. Solusi mengatasi hal itu adalah dengan adanya kebijakan otonomi daerah secara keseluruhan yang meliputi seluruh kabupaten/kota (tingkat dua) dan otonomi khusus untuk beberapa wilayah Provinsi (tingkat satu). Memanfaatkan situasi yang ada, maka daerah-daerah menyampaikan keinginannya sesuai potensi dan ciri khasnya. Hal yang menarik setelah adanya kebijakan otonomi daerah adalah adanya keinginan beberapa daerah untuk menerapkan syariat Islam di daerahnya. ${ }^{10}$

Keberlakuan Undang-undang Nomor 22 tahun 1999 tentang Otonomi Daerah, memungkinkan beberapa daerah membuat peraturan yang berbasis pada ciri khas dan keistimewaan daerah masing-masing. Isu pelaksanaan syariat Islam semakin merebak di beberapa wilayah di Indonesia semenjak diberlakukannya hak otonomi daerah yang memberi peluang bagi setiap daerah mengatur daerahnya masing-masing. Ada beberapa daerah di Indonesia yang melakukan penetapan peraturan daerah bernuansa syariat Islam, salah satunya di Sulawesi Selatan. ${ }^{11}$

Perda mesti tidak bertentangan dengan kepentingan umum, tidak bertentangan dengan aturan yang lebih tinggi, tidak bertentangan dengan Perda lainnya dan sesuai aspirasi masyarakat setempat namun tetap dalam kerangka negara kesatuan. Dalam pembentukan Perda terdapat rambu-rambu yang harus ditaati, ramburambu tersebut yaitu bisa dilaksanakan, materinya tepat, jenis dan

\footnotetext{
${ }^{10}$ Muntoha, Otomomi Daerah dan Perkembangan "Peraturan Daerah Bernuansa Syari'ah” (Yogyakarta: Safiria Insania Press, 2010), 25.

${ }^{11}$ Ibid., 230.
} 
fungsi peraturannya juga tepat. Serta ditambahkan memuat asas kekeluargaan dan kebhinekaan. ${ }^{12}$

Seiring dengan diterapkannya otonomi daerah, secara eksplisit hukum Islam telah diberlakukan sebagai hukum positif. Situasi yang sangat berbeda dengan keadaan sebelumnya karena hukum Islam hanya sebagai hukum yang tak tertulis. Jika sebelumnya penerapan hukum Islam terbatas pada hukum privat yang mengatur antar individu. Namun pada saat ini, hukum Islam telah berlaku di ruang publik yang mengatur relasi antar negara dan individu.

Sejak otonomi daerah digulirkan sampai saat ini diketahui 422 Perda bernuansa syariah dalam berbagai bentuk, yaitu peraturan daerah, keputusan kepala daerah, surat edaran, dan qanun. Produk kebijakan ini berorientasi pada ajaran moral Islam. Perda tersebut hasil rumusan yang digodok secara bersama antara lembaga eksekutif dan legislatif (pejabat daerah) serta melibatkan ormas Islam. Meskipun ada kelompok yang menyatakan Perda ini diskriminatif dan inskonstitusional tetapi sampai saat ini Perda tidak cacat hukum karena dalam otonomi daerah disebutkan setiap daerah bisa menentukan peraturan yang akan diberlakukan di daerahnya. ${ }^{13}$

Bulukumba menjadi daerah pertama Sulawesi Selatan yang menerapkan Perda bernuansa syariat. Menurut sejarah, Kabupaten Bulukumba memiliki histori yang tidak terlepas dari penegakan syariat. Terbentuknya perda bernuansa keagamaan tidak terlepas dari pengaruh aspek. Pertama aspek sejarah bahwa hal ini dipengaruhi oleh adanya penyebaran Islam di Bulukumba yang dilakukan oleh Dato ri Tiro. Islamisasi Dato ri Tiro menjadikan daerah ini sebagai daerah syiar Islam sehingga memberikan filosofi keagamaan yang bernuansa moralitas pada sistem pemerintahan. Kedua, aspek politik lokal dalam hal ini berkaitan dengan perebutan kekuasaan. Implementasi nilai kegamaan bagi perebutan kekuasaan menjadi alat

${ }^{12}$ Muhammad Suharjono, "Pembentukan Peraturan Daerah yang Responsif dalam Mendukung Otonomi Daerah," DiH: Jurnal Ilmu Hukum 10, no. 19 (2014): 2137.

${ }^{13}$ Amril Maryolo, "Syariat dan Perundang-undangan: Geneaologi dan Proses Kebijakan Perda Keagamaan di Bulukumba" (Jakarta: The Semeru Research Institute, t.th.), 3-5. 
penawar untuk menarik simpati publik. Ketiga, gerakan sosial keagamaan yang bertujuan untuk menegakkan syariat Islam di Sulawesi Selatan terkhusus di kabupaten Bulukumba. ${ }^{14}$

Secara historis kebijakan keagamaan yang bernuansa syariat Islam berkembang di Bulukumba sejak tahun 1998 dalam bentuk Crash Program keagamaan yang diinisiasi oleh Andi Patabai Pabokori. Pada saat itu Pemda Bulukumba bersama beberapa tokoh agama merumuskan regulasi yang dimuat dalam beberapa poin Crash Program sebagai payung hukum. ${ }^{15}$

Sejak tahun 2002 di bawah kepemimpinan H. A. Patabai Pabokori pemerintah telah menetapkan beberapa Perda yang bernuansa syariat. ${ }^{16}$ Penegakan syariat Islam di kabupaten Bulukumba tidak lepas dari upaya Komite Persiapan Pelaksanaan Syariat Islam (KPPSI) dalam memperjuangkan formalisasi syariat Islam di Sulawesi Selatan. Secara historis, Sulawesi Selatan pernah menjadi salah satu pusat gerakan Islam garis keras Darul Islam (DI-TII) Kahar Mudzakkar pada awal orde lama. Perseteruan DI-TII dengan pemerintah yang cukup lama secara kultural membentuk kesadaran kolektif Islamisme pada masyarakat. Pasca reformasi, anggapan mengenai kuatnya islamisme di Sulawesi Selatan sehingga dibentuk KPPSI mulai tahun 2000. Ada hal yang mendorong semangat menegakkan syariat Islam di bumi Sulawesi Selatan, adalah adanya pandangan dunia (world view) seluruh komponen Forum Ukhuwah Islamiyah (FUI) yang tergabung dalam sebuah jaringan perjuangan KPPSI. ${ }^{17}$ Bahwa Islam dan politik tidak dapat dipisahkan. Karena itu Islam tidak melulu mengurus masalah privat tetapi juga

${ }^{14}$ Heriansyah Anugrah, Ridho Al-Hamdi, "Kebijakan Syariah di Akar Rumput: Menelusuri Motif Politik Terbitnya Peraturan Desa tentang Hukuman Cambuk di Kabupaten Bulukumba"

${ }^{15}$ Amril Maryolo, "Syariat dan Perundang-Undangan," Mazahibuna; Jurnal Perbandingan Mazhab Jurnal Perbandingan Mazhab 1, no. 1 (2019): 1-24.

${ }^{16}$ Anugrah and Al-Hamdi, "Kebijakan Syariah di Akar Rumput: Menelusuri Motif Kebijakan Syariah di Akar Rumput; Menelusuri Motif Politik Terbitnya Peraturan Desa tentang Hukuman Cambuk di Kabupaten Bulukumba."

${ }^{17}$ Ibid. 
menyelesaikan persoalan kehidupan secara luas (public) di dunia termasuk dunia politik. Islam adalah way of life bagi seluruh manusia atas segala problematika yang mendera kehidupannya untuk dipecahkan, termasuk dalam hal berpolitik.

Penyelenggaraan otonomi atau otonomisasi pemerintah di Kabupaten Bulukumba tampak jelas tidak mengurangi semangat keberagamaan. Sekalipun penanganan bidang agama belum termasuk bidang yang diserahkan kepada daerah otonom, namun bidang tersebut tetap mendapat perhatian Pemerintah kabupaten Bulukumba. Agama justru menjadi visi Kabupaten Bulukumba.

Visi Kabupaten Bulukumba dalam rencana strategis ditegaskan untuk: "mewujudkan Bulukumba sebagai pusat pelayanan di bagian selatan Sulawesi Selatan yang berbasis pada sumber daya lokal yang bernafaskan keagamaan". ${ }^{18}$ Nilai yang bernafaskan Islam tersebut masih ada dalam visi Kabupaten Bulukumba periode 20162021 yaitu: "Masyarakat Bulukumba yang Sejahtera dan terdepan melalui optimalisasi potensi daerah dengan penguatan ekonomi kerakyatan yang dilandasi pada pemerintahan yang demokrasi dan religius." 19

Di Kabupaten Bulukumba sendiri, ada banyak elemen yang menghalangi dalam penerapan Perda syariah. H. A. Patabai Pabokori (mantan Bupati Bulukumba) menegaskan bahwa penerapan syariat Islam sebenarnya bukan hanya keinginan pemerintah akan tetapi keinginan dari masyarakat Bulukumba sehingga mendapat sambutan dari anggota DPRD Bulukumba serta adanya dukungan KPPSI dan Jundullah selaku pendorong terbentuknya Perda syariah di Bulukumba. ${ }^{20}$ Walaupun demikian, tetap ada polemik kebijakan pelaksanaan Perda syariah di Kabupaten Bulukumba. Permasalahan yang muncul baik secara yuridis, implementasi, dan efektivitas pelaksanaannya dari ditetapkannya hingga sekarang.

${ }^{18}$ Amril Maryolo, "Formalisasi Syariat Islam di Bulukumba (Studi tentang Peraturan Daerah Keagamaan), 3-4.

${ }^{19}$ Pemerintah Daerah Bulukumba, "Visi-Misi Kabupaten Bulukumba", diakses pada 9 Oktober 2016). http://www.bulukumbakab.go.id/node/56 (diakses 9 oktober 2016).

${ }^{20}$ Amril Maryolo, "Syariat dan Perundang-Undangan." 
Kabupaten Bulukumba setelah menerapkan Perda syariah telah membentuk 12 desa/kelurahan muslim sebagai salah satu bentuk penerapan Perda syariah dan 12 desa/kelurahan tersebut terbagi di beberapa kecamatan di Bulukumba. Pergantian rezim pemerintahan membuat dinamika kebijakan perda syariah hanya sebatas peraturan tanpa pelaksanaan efektif berbeda ketika saat Perda pertama kali dilegalkan di Bulukumba. ${ }^{21}$

Dari 4 item Perda syariah tersebut, maka sesungguhnya Pemerintah Daerah (Pemda) Bulukumba menjadikan ajaran-ajaran zakat, pandai baca tulis al-Qur'an, pemakaian busana muslim, dan larangan mengonsumsi minuman beralkohol/khamar yang merupakan objek hukum Islam menjadi hukum positif melalui pembentukan peraturan daerah keagamaan. ${ }^{22}$

\section{Formalisasi dan Penerapan Perda Syariah di Kabupaten Bulukumba}

a. Perda Bulukumba Nomor 7 Tahun 2015 Tentang Pengelolaan Zakat

Bupati Patabai Pabokari yang menjadi pencetus Perda Syariat Islam di Bulukumba tahun 2003 menjelaskan bahwa salah satu alasan penyusunan RUU pengelolaan zakat karena regulasi sebelumnya belum mengatasi dan memaksimalkan potensi zakat. Pengelolaan zakat belum terarah dan terpadu. Aspek kerangka hukum, kebijakan, dan implementasi belum terlaksana dengan baik. Kondisi Sebelum Lahirnya Perda tentang Pengelolaan Zakat Profesi, Infaq, dan Shadaqah di Kabupaten Bulukumba dilatar belakangi oleh tingkat kesadaran umat Islam di Bulukumba dalam memenuhi kewajiban membayar zakat, infaq dan sedekah yang masih rendah. ${ }^{23}$

${ }^{21}$ Mustari dan A Nuraulia M, "Implementasi Peraturan Daerah Kabupaten Bulukumba Nomor 06 Tahun 2003 tentang Pandai Baca Al-Qur'an bagi Calon Pengantin,” Jurnal Supremasi 13, no. 1 (2018): 1-13.

\footnotetext{
${ }^{22}$ Amril Maryolo, "Formalisasi Syariat Islam di Bulukumba, 4-5.

${ }^{23}$ Amril Maryolo, "Syariat dan Perundang-Undangan."
} 
Dulu saat Perda ini masih berjalan, bupati, asisten, dan pejabat wajib menghitung zakat di depan umum setiap tahun. Pengumpulan dan penggunaan zakat di umumkan ke masyarakat luas melalui masjid. Namun saat penelitian ini dilakukan, di bawah kepemimpinan bupati pengganti ada gejala semangat membayar zakat cenderung kian terkikis. Salah satu alasannya pihak Bazisda (Badan Amil Zakat Infak dan Sadaqah Daerah) sebagai pengelola dinilai kurang transparan dan tidak optimal memasyarakatkan dan melaporkan pemanfaatan zakat.

Sekretaris Provinsi Sulsel, berinisial AM menjelaskan pandangannya tentang pelaksanaan kebijakan pengelolaan zakat di Bulukumba pasca kepemimpinan Bupati Patabai Pabokari. AM mengatakan tingkat kemiskinan di Sulsel mencapai 1 juta jiwa. Pemerintah daerah Bulukumba cenderung mampu untuk menurunkan hingga 10 persen per tahun jika ada dana yang bisa dialokasikan untuk mendorong penciptaan usaha bagi kaum dhuafa. Untuk itu, peraturan mendasar mengenai operasionalisasi penanganan zakat sangat diperlukan. Konsep untuk jaminan sosial, infaq dan sedekah bisa digunakan untuk program alih profesi para penjual ballo (minuman semacam tuak), penjual kupon dan bandar judi kecil, preman pasar dan preman pesisir, menjadi pedagang, supir angkutan, penarik becak, wirausaha perbengkelan dan seterusnya.

Perda Syariat Islam diawali di era reformasi melalui terbentuknya KPPSI. Kemudian berlanjut dengan lahirnya Perda Syariat Islam di Bulukumba yang menjadi daerah pertama. Namun, Muallim justru menyesalkan karena implementasi perda tersebut pasca kepemimpinan Bupati Patabai Pabokari justru semakin kendor. Padahal di awal kelahirannya, nafas tersebut mewabah hingga kebeberapa kabupaten bahkan tingkat provinsi. Pemprov Sulsel sudah melahirkan Perda Zakat Nomor 7 tahun 2015. ${ }^{24}$

Hal senada dikatakan Pengurus Badan Amil Zakat (BAZ) Bulukumba yang menguraikan bahwa pada zaman Bupati Bulukumba Patabai Pabokari, pembayaran zakat profesi dari instansi relatif lancar masuk ke BAZ. Termasuk bentuk zakat lain setelah 
banyak bersosialisasi wajib zakat banyak berdatangan di kantor BAZ untuk menyerahkan sendiri. Hanya saja lewat periode beliau, masa bupati Sukri Sappewali, pengelolaan zakat profesi mulai "dikaburkan" dan menurun semangatnya. ${ }^{25}$

Ada kondisi bahwa pembayaran zakat sangat tergantung oleh keinginan dan kesadaran pegawai negeri. Pembayaran zakat oleh profesi non PNS seperti supir, pengusaha, polisi, TNI, dan lainnya belum terkelola dan tersosialisasikan dengan optimal. Awal bulan Mei 2010, pengurus BAZ Bulukumba berupaya bertemu lagi dengan Sukri Sappewali ,bupati pengganti Patabai Pabokari. Hasilnya, bupati merespon untuk kembali merealisasikan zakat profesi ini. Namun ketika ditanyakan kepada masyarakat, narasumber masih mempertanyakan transaparansi dan peruntukkan zakat tersebut perlu diumumkan secara garis besar melalui media masa dan radio lokal.

Humas Pemda Bulukumba menjelaskan ada beberapa strategi penegakkan Perda Zakat Profesi, antara lain lewat sosialisasi di beberpa Seminar lokal, membentuk desa pelopor Zakat (Percontohan), pembentukan Unit Pengelola Zakat (UPZ) di masingmasing Desa/Kelurahan dan Instansi.

Anggota masyarakat dan narasumber wartawan lokal, Radar Bulukumba memberikan pandangan bahwa tingkat kesadaran masyarakat, pegawai negeri, pengusaha untuk melaksanakan kewajibannya membayar zakat, infak, dan sedekah mengalami peningkatan pada masa bupati Patabai, dan menurun pada periode bupati penggantinya. Pada masa Bupati Patabai telah terbentuk 12 Desa Pelopor Zakat/Desa Muslim, Pemberian bantuan kepada siswa - siswi kurang mampu melalui dana Bazkab, Bantuan kepada Sarana Peribadatan, Ekonomi Lemah, TPA/TKA dan Madrasah.

b. Perda Bulukumba Nomor 3 Tahun 2002 Tentang Minuman Beralkohol

Perda Nomor 3 Tahun 2002 berisi tentang Larangan, Pengawasan, Penertiban, Peredaran dan Penjualan Minuman

\footnotetext{
${ }^{25}$ Amril Maryolo, "Syariat Dan Perundang-Undangan.”
} 
Beralkohol. ${ }^{26}$ Perda minuman beralkohol ini antara lain mengatur jarak penjualan terhadap tempat ibadah, sekolah dan perkantoran Pemda, TNI dan Polri, minimal satu kilometer. Selain itu, diatur pula bahwa yang boleh menjual miras itu hanya tempat-tempat daerah obyek wisata yang memiliki hotel yang didatangi orang asing, seperti di kawasan wisata Pantai Bira dan Bonto Bahari.

Sebelum tahun 2002 banyak pedagang menjual minuman keras dan pembelinya para pemuda setempat. Setelah adanya perda minuman beralkohol hanya diperbolehkan di kawasan hotel di tempat obyek wisata tidak di pemukiman apalagi sekolah dan perkantoran. ${ }^{27}$ Hal yang diatur adalah bukan pelarangan total, hanya pengaturan dimana saja tempat miras boleh dan dilarang diperjualbelikan. Bila hal dikatakan terkait dengan keagamaan maka tidak sepenuhnya demikian namun hal ini dapat menyentuh. Pada prinsipnya pemerintah melarang penyalahgunaan alkohol secara umum bukan pada tempatnya. Hanya pola pendekatannya secara keagamaan.

Sebelum lahirnya Perda pengaturan minuman beralkohol, diceritakan adanya keadaan maraknya minuman keras yang beredar di kalangan masyarakat Bulukumba. Keadaan itu terkait dengan perilaku kriminal yang meningkat sebagai dampak minuman keras. Stabilitas ketertiban dan keamanan terganggu dengan banyaknya pemabuk yang melakukan tindakan perkelahian, pencurian, perjudian, pembunuhan. $^{28}$

Pemda beserta jajarannya seperti Kesbangpolinmas dan Satpol Pamong Praja melakukan upaya sosialisasi dan pendekatan persuasif terhadap pemuda pemakai Miras dan pedagang penjual miras, termasuk jenis minuman lokal setempat yang memabukkan; melakukan tindakan tegas terhadap pelanggaran Perda; membentuk Tim Buserda (Buru dan Sergap Daerah); melakukan operasi pengawasan dan penenindakan miras di lapangan; mengembangkan

${ }^{26}$ Peraturan Daerah Bulukumba Nomor 03 Tahun 2002 tentang Larangan, Pengawasan, Penertiban, Peredaran dan Penjualan Minuman Beralkohol.

${ }^{27}$ Rahmatiah HL, "Efektivitas Penerapan Pengendalian dan Pengawasan Miras di Makassar," Al Daulah: Jurnal Hukum Pidana dan Ketatanegaraan 5, no. 2 (2016): 398-411.

${ }^{28}$ Amril Maryolo, "Syariat Dan Perundang-Undangan." 
Majelis-majelis Taklim untuk meningkatkan keimanan dan ketakwaan warga Bulukumba; pemberian bantuan modal usaha untuk pengalihan profesi yang tidak bertentangan dengan syariat Islam; membuka jaringan pengaduan bagi masyarakat tentang peredaran miras sehingga bisa ditangani lebih lanjut.

Ada kecenderungan indikasi positif secara bertahap sebagai implikasi sosial akibat adanya Perda pengendalian minuman keras di Kabupaten Bulukumba dan hasilnya adalah angka kejadian kejahatan yang dapat menjadi parameter tingkat kriminalitas cenderung menurun secara drastis sekitar $80 \%$, antara kurun waktu 2002 hingga $2005 .^{29}$

Stabilitas ketertiban dan keamanan kondusif sejak Pemda Bulukumba beserta jajarannya telah melakukan operasi penertiban dan pemusnahan miras dari jenis yang dibuat di luar daerah \pm 250.000 botol dan minuman tuak lokal \pm 15.000 liter. Data tersebut merupakan hasil operasi lapangan Polres Bulukumba. yang bernuansa semangat agama, yang disebut crash program bidang keagamaan itu terdiri dari empat perda yang disusun Pemda dan DPRD untuk mengatur minuman beralkohol, mengajak masyarakat Bulukumba yang mayoritas muslim (sebanyak 99\%) untuk mengendalikan dirinya sebagai pelaku dan korban kejahatan.

Sebelum tahun 2002 di Bulukumba sering ditemukan anak muda yang mabuk-mabukan dan berujung pada tawuran. Dengan adanya dasar hukum Perda, maka kebiasaan minum ballo dan minuman keras lainnya ditertibkan semua. Pada masa bupati H. A. Patabai Pabokari, dengan pendayagunaan dana zakat profesi, infaq dan sadekah, maka penduduk yang menjual miras dialihkan profesinya dan pemuda yang menganggur diberikan jalan dan modal usaha untuk bekerja sebagai pedagang, usaha bengkel, supir angkot, direkrut sebagai Satpol PP, dan usaha halal lainnya yang mereka kehendaki.

\footnotetext{
${ }^{29}$ Rahmatiha HL, "Efektivitas Penerapan Pengendalian dan Pengawasan Miras di Makassar."
} 
c. Perda Nomor 5 Tahun 2003 Tentang Pakaian Muslim dan Muslimah

Ada data yang dikumpulkan pihak Pemda Bulukumba bahwa tingkat pemakaian busana muslim (jilbab) khususnya siswi SLTP, SLTA dan Perguruan Tinggi sebelum Perda diberlakukan hanya berkisar $\pm 2 \%$, tingkat pemakaian busana muslim (jilbab) di kalangan masyarakat $\pm 5 \%$; Tingkat Pemakaian Busana Muslim bagi Karyawati Pemda Bulukumba $\pm 6 \% .^{30}$

Strategi ditempuh dengan prinsip contoh, ketauladan dan program pemberian bantuan pakaian Muslim secara gratis kepada warga masyarakat di desa muslim. Sosialisasi dilakukan dengan turun ke sekolah-sekolah dan majelis taklim di tengah masyarakat. Juga diadakan lomba-lomba disain dan peragaan busana muslim mulai tingkat SD, SLTP, SLTA, majelis taklim dan masyarakat umum serta membentuk iim dakwah busana yang menutup aurat dan melakukan himbauan melalui tempat pelayanan umum seperti Puskesmas, Rumah Sakit, Pasar dan Karang Taruna. ${ }^{31}$

Pemda lewat Humas melaporkan bahwa setelah pemberlakuan Perda Busana Muslim Bulukumba secara persuasif, ketaladanan dan fasilitasi pemberian pakaian secara cuma-cuma maka tingkat Pemakaian Busana Muslim khususnya Siswi SLTP, SLTA dan Perguruan Tinggi yang beragama Islam dan hasilnya hampir seratus persen berbusana muslim dengan sukarela. Perda ini hanya diberlakukan untuk kalangan Muslim dan tidak pernah diberlakukan apalagi dipaksakan bagi penduduk yang non-Muslim di Bulukumba, seperti para pedagang etnis Tionghoa atau penduduk Nasrani yang berasal dari kawasan Indonesia bagian Timur lainnya.

d. Perda Nomor 6 Tahun 2003 tentang Pandai Baca Al-Qur'an bagi Siswa dan Calon Pengantin

Secara historis, terdapat alasan diperlukannya kepandaian membaca Al Qur'an bagi warga Muslim Bulukumba. Perkembangan

\footnotetext{
${ }^{30}$ Amril Maryolo, "Syariat dan Perundang-Undangan."

${ }^{31}$ Peraturan Daerah Bulukumba Nomor 05 Tahun 2003 tentang Berpakaian Muslim dan Muslimah di Kabupaten Bulukumba.
} 
syariat Islam dimulai pada saat kehadiran ulama tasawuf Khatib Bungsu yang bergelar Dato Ri Tiro pada awal abad ke $17 \mathrm{M}$. Diperkirakan Jumlah Penduduk Bulukumba yang Buta Aksara AlQur'an $\pm 20 \%$ dari 360.126 jiwa $( \pm 72.252$ jiwa). Selain itu ada kenyataan bahwa tingkat kesadaran masyarakat Bulukumba untuk mempelajari, membaca, mendalami dan mengamalkan Al-Qur'an masih rendah. ${ }^{32}$ Adapun strategi yang dilakukan adalah:

1) Melakukan pendataan terhadap kelompok-kelompok pengajian tradisional yang dilakukan oleh masyarakat untuk dibina dalam bentuk pengajian modern.

2) Menginstruksikan pembentukan TKA/TPA (TKA usia 4-6 tahun, TPA usia 7-12 tahun) dari tingkat kabupaten sampai kecamatan, desa dan TPA orang tua.

3) Memperkuat fungsi dan peranan lembaga BKPRMI Kabupaten Bulukumba sebagai leading sektor pembinaan dan pengembangan dan pendataan dan pengorganisasian lembaga TPA/TKA. Selain itu, mengembangkan teknik pembinaan baca tulis Al-Qur'an serta memantau, mengendalikan dan mengkoordinasikan kegiatan TKA/TPA kepada Bupati Bulukumba

4) Menyediakan anggaran pembinaan TKA/TPA melalui pos APBD sejak tahun 1995 sampai sekarang (bantuan pembinaan berupa dana pengelolaan, dana pengadaan sarana prasarana pendukung belajar dan bantuan material berupa Al-Qur'an, buku metode Iqra dan Toga wisuda).

5) Komitmen Bupati menghadiri acara wisuda dan sebagai penguji dalam kegiatan.

6) Mengangkat tenaga kontrak ngaji yang disebar keseluruh TPA/TKA dalam wilayah Kabupaten Bulukumba (tahun 2004 dimulai dengan jumlah guru 160 orang).

${ }^{32}$ Peraturan Daerah Kabupaten Bulukumba Nomor 06 Tahun 2003 tentang Pandai Baca Al-Qur'an bagi Siswa dan Calon Pengantin dalam Kabupaten Bulukumba. 
7) Menjalin kerja sama dengan IAIN/UIN Alauddin Makassar melalui Program Diploma II Instruktur Baca Tulis Al-Qur'an (IBTQ).

8) Memasyarakatkan Al-Qur'an melalui pemberian hadiah tambahan berupa Al-Qur'an kepada pemenang lomba olahraga dan seni.

9) Penunjukan organisasi LPPTKA-BKPRMI untuk mengeluarkan Ijazah/Sertifikat pandai baca tulis AlQur'an (SK BKDA No. 307/VI/2004).

10) Menetapkan kebijakan mata pelajaran Al-Qur'an sebagai muatan lokal di SD, SMP dan SMA dengan menambah jam pelajaran Agama menjadi 4 jam setiap minggu (SK Bupati No. 306/VI/2004 tentang Pembentukan Tim Penyusun Kurikulum Muatan Lokal Mata Pelajaran AlQur'an).

11) Bekerjasama dengan Departemen Agama Bulukumba, memprogramkan kegiatan pembinaan baca Al-Qur'an bagi para calon jamaah haji.

12) Memberikan penghargaan/satya lencana kepada para pembina TPA/TKA berprestasi dan tokoh-tokoh agama.

13) Menyelenggarakan Festival Anak Saleh (FASI) setiap tahun dan porseni pemuda remaja masjid yang dimulai sejak tahun 1996 sampai sekarang.

14) Menetapkan kebijakan Pemerintah Daerah tentang pemberlakuan persyaratan pandai baca Al-Qur'an bagi calon Pegawai Negeri Sipil (SK No. 800/5701/2003), calon siswa SLTP, SLTA dan Perguruan Tinggi, pegawai yang akan naik pangkat termasuk guru sebagai tenaga fungsional, calon mempelai/pengantin, pegawai yang akan dipromosikan menduduki jabatan struktural maupun fungsional, calon Kepala Desa, Perangkat Desa dan BPD, sesuai surat Bupati No. 240/84/PMD, Calon Jamaah Haji.

15) Membentuk tim pemantauan pelaksanaan Perda Nomor 5/2003 dan Perda No. 6/2003 ditiap jenjang pendidikan (SK Bupati Nomor 308/VI/2004). 
16) Membentuk tim fasilitasi kegiatan Crash Program Pemerintah Kabupaten Bulukumba Bidang Keagamaan, (SK Bupati Nomor Kpts. 305/VI/2004).

17) Pembentukan tim penguji tetap bagi pejabat yang akan menduduki jabatan struktural dan fungsional.

18) Mengeluarkan Surat Edaran Bupati kepada para Kepala Sekolah SLTP, SMU/SMK, tentang pelaksanaan Perda keagamaan di sekolah-sekolah (SE Nomor 378b/DPDIK/IX/2003).

19) Menjalin kerjasama dengan Fakultas Dakwah IAIN Alauddin Makassar Bidang Diploma II Bimbingan Penyuluhan Agama Islam.

20) Melaksanakan Gerakan Wakaf Al-Qur'an.

21) Pemberian bantuan pakaian Wisuda (Toga) TPA/TKA kepada para Ketua BKPRMI Kecamatan sebanyak 2.000 pasang.

22) Mengembangkan sekolah-sekolah Arab dan Madrasah Diniyah.

23) Membentuk Sekolah Model Islam di tingkat TK, SD dan SLTP.

24) Mengembangkan Hifzil Qur'an di Pesantren-pesantren dengan memberikan bantuan fisik dan Bea Siswa bagi santri.

25) Membuat dan mempersiapkan Desa Muslim.

Ada beberapa dampak yang terjadi pasca pemberlakuan perda baca tulis Al-Qur'an di tengah masyarakat. Setelah lima tahun penerapan, diketahui bahwa jumlah Buta Aksara Al-Qur'an di kalangan penduduk Bulukumba mengalami penurunan sebanyak lebih kurang sebesar $5,5 \%$.

Selain itu Humas Pemda Bulukumba melaporkan bahwa tingkat kesadaran masyarakat dalam mempelajari, membaca, mendalami dan mengamalkan Al-Qur'an meningkat dengan berkembangnya TPA (Taman Pendidikan Al Qur'an/TKA (Taman 
Kanak-kanak Al Qur'an) sebanyak 648 buah, Majelis Taklim 143 buah). ${ }^{33}$

\section{Penutup}

Formalisasi dan penerapan Perda Syariah di Bulukumba dapat menimbulkan dua aspek dan dapat dikatakan berjalan dengan baik. Hal ini didasarkan karena adanya perkembangan pemahaman dan kepatuhan masyarakat Bulukumba terhadap Perda bernuansa syariah tersebut. Sisi lain dapat dikatakan kurang efektif karena masih banyaknya masyarakat Bulukumba yang tidak mengetahui apalagi memahami dengan baik Perda syariah tersebut.

\section{Referensi}

Abdul Syatar. "Transformation of Fiqh in The Forms ff Hajj And Zakat Legislation." Mazahibuna; Jurnal Perbandingan Mazhab 1, no. 2 (Desember 2019): 120-133. http://journal.uinalauddin.ac.id/index.php/mjpm/article/view/11646.

Anugrah, Heriansyah, and Ridho Al-Hamdi. "Kebijakan Syariah di Akar Rumput: Menelusuri Motif Kebijakan Syariah di Akar Rumput; Menelusuri Motif Politik Terbitnya Peraturan Desa Tentang Hukuman Cambuk di Kabupaten Bulukumba." Politea: Jurnal Politik Islam 3, no. 2 (2020): 185-212.

Anwar, M. Zainal. "Formalisasi Syari'at Islam di Indonesia: Pendekatan Pluralisme Politik Dalam Kebijakan Publik." Millah: Jurnal Studi Agama 10, no. 2 (2011): 192-221. https://www.academia.edu/25382405/Formalisasi_Syari_at_Isla m_di_Indonesia_Pendekatan_Pluralisme_Politik_dalam_Kebijak an_Publik.

Halim, Fatimah. "Obsesi Penerapan Syari'at Islam di Wilayah Lokal." Ad-Daulah 4, no. 2 (2015): 354-365.

Herdiansyah, Haris. Metodologi Penelitian Kualitatif untuk Ilmu-Ilmu Sosial. Jakarta Selatan : Selemba Humanika, 2010.

HL, Rahmatiah. "Efektivitas Penerapan Pengendalian Dan Pengawasan Miras Di Makassar." Al Daulah: Jurnal Hukum

${ }^{33}$ Syafuan Rozi dan Nina Andriana, "Politik Kebangsaan dan Potret Perda Syariah di Indonesia: Studi Kasus Bulukumba dan Cianjur" (Jakarta: Pusat Penelitian Politik, t.th.), 10-18. 
Pidana dan Ketatanegaraan 5, no. 2 (2016): 398-411.

Listianingsih, Dessy Marliani. "Analisis Pelaksanaan Peraturan Daerah Berbasis Syariah Provinsi Aceh Dalam Perspektif Hak Asasi Manusia." Staarrecht: Indonesian Constitutional Law Journal 3, no. 1 (2019): 105-128.

Maryolo, Amril. "Syariat dan Perundang-undangan." Mazahibuna; Jurnal Perbandingan Mazhab Jurnal Perbandingan Mazhab 1, no. 1 (2019): 1-24. . "Formalisasi Syariat Islam di Bulukumba (Studi Tentang Peraturan Daerah Keagamaan). Yogyakarta: Pascasarjana UIN Sunan Kalijaga, 2017.

Muntoha. Otomomi Daerah dan Perkembangan "Peraturan Daerah Bernuansa Syari'ah.” Yogyakarta: Safiria Insania Press, 2010.

Mustari, and A Nuraulia M. "Implementasi Peraturan Daerah Kabupaten Bulukumba Nomor 06 Tahun 2003 tentang Pandai Baca Al-Qur'an Bagi Calon Pengantin.” Jurnal Supremasi 13, no. 1 (2018): 1-13.

Peraturan Daerah Bulukumba Nomor 03 Tahun 2002 tentang Larangan, Pengawasan, Penertiban, Peredaran dan Penjualan Minuman Beralkohol.

Peraturan Daerah Bulukumba Nomor 05 Tahun 2003 tentang Berpakaian Muslim dan Muslimah di Kabupaten Bulukumba," 2003.

Peraturan Daerah Bulukumba Nomor 7 Tahun 2015 tentang Pengelolaan Zakat.

Peraturan Daerah Kabupaten Bulukumba Nomor 06 Tahun 2003 tentang Pandai Baca Al-Qur'an bagi Siswa dan Calon Pengantin dalam Kabupaten Bulukumba," 2003.

Pemerintah Daerah Bulukumba. "Visi Misi Kabupaten Bulukumba". $\begin{array}{lllll}\text { Diakses } & \text { pada } & 9 & \text { Oktober } & 2016\end{array}$ http://www.bulukumbakab.go.id/node/56 .

Pemerintah Kabupaten Bulukumba. "Pengertian Produk Hukum Daerah." Diaskses pada 29 April 2015. http://www.hukumsetda.bulelengkab.go.id/ 
Rozi, Syafuan dan Nina Andriana. Politik Kebangsaan dan Potret Perda Syariah di Indonesia: Studi Kasus Bulukumba dan Cianjur. Jakarta: Pusat Penelitian Politik, t.th.

Suharjono, Muhammad. "Pembentukan Peraturan Daerah yang Responsif dalam Mendukung Otonomi Daerah.” DiH: Jurnal Ilmu Hukum 10, no. 19 (2014): 21-37.

Wikipedia. "Perda Syariah". Terakhir diperbaharui 10 bulan yang lalu. https://www.id.m.wikipedia.org/

1. Dosen Tetap Prodi Perbandingan Mazhab Universitas Islam Negeri Alauddin Makassar.

2, 3, 4, 5, 6, 7. Mahasiswa Prodi Perbandingan Mazhab Universitas Islam Negeri Alauddin Makassar 